\title{
Human Gene Mutations and Migratory Flows-Portugal and the Mediterranean
}

\author{
Leonor Osório Almeida \\ Laboratório de Genética Molecular, Departamento de Ciencias da Vida, Faculdade de Ciências e Tecnologia, \\ Universidade Nova de Lisboa, Campus da Caparica, Caparica, Portugal \\ Email: $\underline{\text { mlo@fct.unl.pt }}$
}

Received 29 June 2015; accepted 16 August 2015; published 19 August 2015

Copyright @ 2015 by author and Scientific Research Publishing Inc.

This work is licensed under the Creative Commons Attribution International License (CC BY).

http://creativecommons.org/licenses/by/4.0/

(c) (i) Open Access

\section{Abstract}

This study presents a compilation of results obtained by several research groups on the mutational analysis of $\beta$ thalassemia in Portugal and in Morocco, and compares the mutation/haplotype associations in both countries. We use the $\beta$ thal mutations and haplotypes as genetic markers to address the question of gene flows through the Mediterranean basin area into the Iberian Peninsula and Portugal since the Phoenician trade up to recent times.

\section{Keywords}

\section{$\beta$ Thalassemia, Genes, History}

\section{Introduction}

Human gene mutations and its genomic background, hereby defined by a set of nuclear DNA polymorphisms in high linkage disequilibrium (haplotype), constitute a valuable tool for the analysis of the human gene geography. Hereditary hemoglobin diseases, being restricted to certain world regions, in part due to environmental factors such as the selective pressure of malaria, allow analysing genetically homogeneous populations defined with a statistically significant probability by its $\beta$ globin gene cluster haplotype (Antonarakis et al., 1985; Flint et al., 1993).

Although data exist on $\beta$ thalassemia ( $\beta$ thal) mutations, few are known about the mutation/haplotype associations and its comparative analysis between countries, in order to deepen the study of demographic processes with those powerful genetic markers. We undertook this analysis, starting with a comparison among Portugal and Morocco, taking into account our history, and placing it into the geographic context of Europe and the Mediterranean area.

The territory of mainland Portugal, situated in the West of the Iberian Peninsula (IP), received during millen- 
nia several civilizations and genes from Africa, Middle East, Central and Northern Europe, and, in the XVth century, from sub Saharan Africa. Local people, the Iberians have an undefined origin. Some authors argue for a North African origin-data on Y chromosome in Portugal favours this hypothesis. Portugal was founded in the territory where Phoenicians established colonies, Celts and Iberians intermixed, and the long lasting occupations of Romans, Visigoths and Arabs left their genes and cultures. The pattern of the distribution and the frequency of present $\beta$ thal genes in Portugal, reflects its geographical location and history, to be considered together with environmental factors such as the prevalence of malaria, endemic up to the middle of the XXth century (BruceChwatt et al., 1980). The ecosystems favourable to originate foci of malaria are the wet areas of rice culture situated in river Mondego, the valleys of the lower Tagus, lower Sado and Guadiana rivers. There, settled populations of African slaves brought back by the African conquests of the XVth century and their $\beta S$ genes.

So, from the Iron Age onwards, the Peninsular Southwest saw the implantation of a Semite, Mediterranean culture, in its indigenous Bronze Age people, the Cinetes (in Southwest Portugal), the Tartessians (Andaluzia) and the Iberians (Southeast Spain) (Brit. Enc., 1969). Around 700 BC, Greeks from Focida took away to the Phoenicians its hegemony of trade with Tartessos (Mata, 1993). Phoenicians and Carthaginians spread its influence into the southern and western coasts of Portugal (Tavares, 1993; Varela Gomes, 1993) establishing fisheries in Algarve, Alcacer (Sado river) and Tagus river, up to the north. Anthropologists found vestiges of Phoenician and Punic colonies in the Central and Northern coasts (Aveiro, Povoa do Varzim and Ancora) (Tavares, 1993). After the second Punic war, the Carthaginians were expulsed from the IP (206 BC) and the Romans started its occupation which lasted for four centuries. In $400 \mathrm{AD}$, the IP was invaded by Germanic tribes from the North: the Alans (Russian stepes), the Sueves (Germanic) and shortly after by the Goths (from the Baltic region). The Goth kingdom spread in the North and South of Douro river ruling stably for 300 years until 711 AD, when the Islamisation of the IP took place. Permanence of the Islam lasted up to the Reconquista in 1000 AD in the North of IP. In 1094, the Almoravides conquered Lisbon, city recuperated in 1143. From 1250 on, the territory of actual Portugal was conquered to the moors.

\section{Study Population}

The mutation data included in this compilation consisted of $561 \beta$ thalassemia ( $\beta$ thal) independent chromosomes from Portugla (Faustino et al., 1999) and of $187 \beta$ thal chromosomes from Morocco (Lemsaddek et al., 2004).

Mutation/haplotype data was obtained with $70 \beta$ thal independent chromosomes (Faustino et al., 1992; Gonçalves et al., 1998) and $187 \beta$ thal chromosomes from Morocco.

\section{Results}

In Portugal, the prevalence of the $\beta$ thal trait is $1.06 \%$ in the South (which comprises Algarve, Alentejo, up to the Tagus valley), decreasing to $0.47 \%$ in the Centre, mostly in the Coast, and to $0.03 \%$ in the North (North of Douro river) (Martins et al., 1993, Inez et al., 1993). The mutational spectrum agrees with the Mediterranean pattern where we observe a decreasing gradient of the IVS1-110 from East to West and, inversely, an increase of CD 39 from East to West of the Mediterranean basin Figure 1. The six most frequent $\beta$ thal mutations are CD 39, IVS 1-1, IVS 1-6, IVS 1-110, CD15 (TGG-TGA) and CD 6 (-A). The geographic distribution is heterogeneous, according to a statistical analysis of data from several previous studies (Faustino et al., 1999). The nonsense CD 39 and IVS 1-1 mutations are predominant in the South, IVS 1-6 and CD 15 in the Centre, and CD 6(-A) displays an exclusive presence in the North, in a different haplotype from the one present in Northern Africa (Cabeda et al., 1999). The mutation IVS 1-110 is distributed all over the country (Figure 2).

In Morocco the six major mutations are: CD 39, IVS 1-6, FS CD 6 (-A), FSCD 8 (-AA), IVS 1-1 and CD -29 (A-G) (Lemsaddek et al., 2004).

A regional predominance of IVS 1-6 was observed in Gharb and West regions. The mutation and Orkin's haplotype associations are similar in Portugal and Morocco, and different from other Mediterranean basin countries Table 1.

\section{Discussion}

The prevalence of hemoglobinopathies and the regional heterogeneity of $\beta$ thal mutations in Portugal are in 


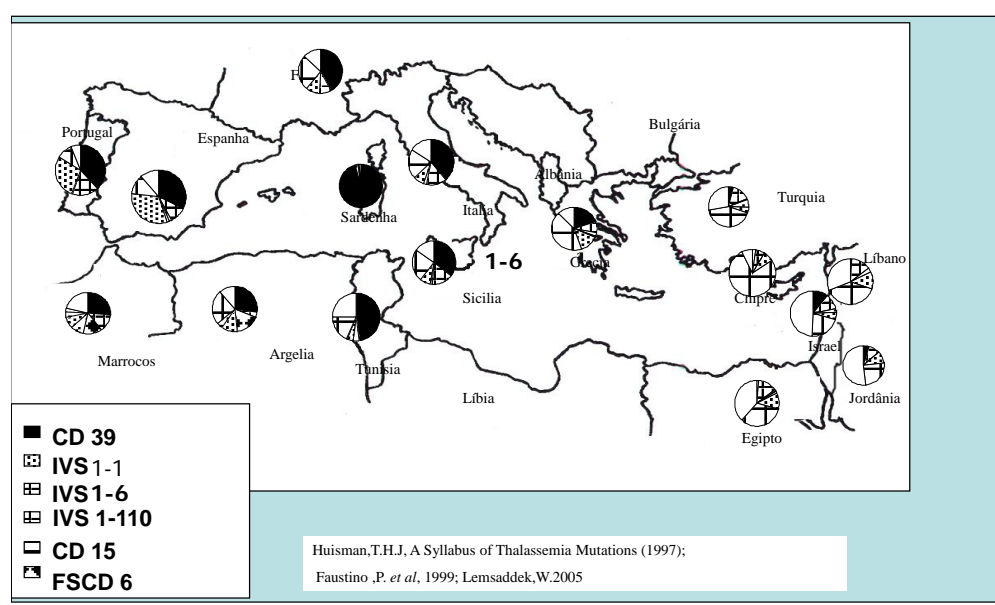

Figure 1. Beta thalassemia mutation distribution in the Mediterranean.
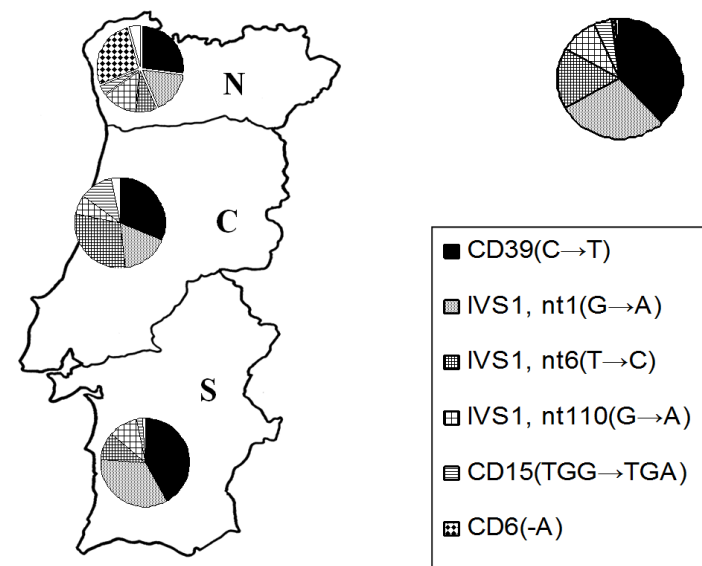

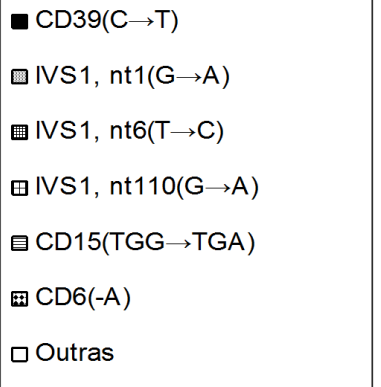

Figure 2. Beta thalassemia mutational spectrum inPortugal.

Table 1. Association of major $\beta$ thalassemia mutation/haplotype in the Mediterranean area.

\begin{tabular}{|c|c|c|c|c|c|c|}
\hline \multicolumn{7}{|c|}{ Country [Ref.] } \\
\hline & Morocco & Algeria & Tunisia & Egypt & Portugal & Italy \\
\hline Mutation & [1] & [2] [3] & [4] & [5] & {$[6][7]$} & [8]-[10] \\
\hline CD 39 & I; II & I; II; B & I; II; A; 5a & II & I; II & I; II; VII'; IX \\
\hline IVS-1-6 & VI; VII & VI; D & VI & VI & VI; VII & VI; VII ${ }^{\mathrm{a}} \mathrm{X}^{\mathrm{a}}$ \\
\hline IVS-1-110 & I; II & I; II & I & I; II & I & $\mathrm{I} ; \mathrm{II}^{\mathrm{b}} ; \mathrm{IX}^{\mathrm{a}}$ \\
\hline FSC 8 & IV; VI; VII & - & - & - & - & - \\
\hline FSC 6 & III; IX; A & I; IX; A & IX; A & $\mathrm{Va}$ & E & $\mathrm{I}^{\mathrm{b}} ; \mathrm{IX}^{\mathrm{b}}$ \\
\hline IVS $1-1$ & IV; V; IX & I, III, V, IX, A & $\mathrm{Va}$ & $\mathrm{Va}$ & III; V; IX & $\mathrm{II}^{\mathrm{a}} ; \mathrm{V}$ \\
\hline
\end{tabular}

${ }^{a}$ Haplotype in Sicily [5] Waye et al., 1999; baplotype in Sardinia [1] Lemsaddek et al., 2004; [2] Bennani et al., 1994; [3] Rouabhi et al., 1988; [4] Chibani et al., 1988; [6] Faustino et al., 1992; [7] Cabeda et al., 1999; [8] Pirastu et al., 1988; [9] Schiliro et al., 1995; [10] Rosatelli et al., 1992.

accordance with its ecogeography and history. The long mountain range (the Cordillera Central) crosses the IP, running North of Tagus River from East to West, thus creating a natural boundary North/Centre and South of 
Portugal. The South is crossed by major rivers Tagus, Sado and Guadiana where foci of malaria existed until middle XXth century.

The existence of genetic compounds such as $\beta S / \beta$ thal (Faustino et al., 1992) or $\beta S / H b$ Lepore (Gonçalves et al., 2002) shows the easy mixing of the authoctonous population with incoming people.

$\beta$ thalassemic chromosomes are particularly suitable as genetic markers for two main reasons each mutation has a close association with a specific haplotype, the mutational spectrum being characteristic of each population, and there is a reduced chromosomal haplotypic variation as compared to the normal ones. In the countries of the Mediterranean Basin we observe 9 independent mutational events associated to one of 9 haplotypes, in $80 \%$ of the cases (Antonarakis et al., 1982).

The haplotypic diversity can still be reduced to 6 (I, II, V, VII, VIII and the group III, IV, IX) according to framework.

Portugal and Morocco exhibit 4 common mutations: CD39, IVS1-1, IVS1-6 and IVS1-110 in the same haplotypes (Table 1). This spectrum is in accordance with the.Moorish presence which lasted for 500 years in Portugal (Torres, 1992).

The major $\beta$ thal mutation in Portugal, CD 39, common to all the populations of the Mediterranean basin (42\% of relative frequency, in the South), arises in association with haplotypes I and II, as observed in Morocco (36\% of relative frequency). The mediterranean occurrence of this mutation in all three $\beta$ gene frameworks and fifteen associated haplotypes, according to Flint et al., 1993 suggests an ancient mutational event which, according to Cao et al. 1989; Faustino et al., 1992 probably occurred in the Phoenicians in the XIIth to XIth centuries BC. If we hypothesize a near eastern origin for the beta thalassemia in Portugal and, given that no Jewish traces exist in the South from the XVIth century on, we have to postulate a previous origin. The unique interaction with Semite populations would have taken place in the Protohistory with the Phoenician presence. Increasing archaeologic vestiges of the Phoenicians in Algarve (Tavira), Alentejo (Alcacer do Sal), Lisbon region (Setubal, Almaraz), Santarém (M. Varela Gomes, pers. comun.), give consistency to the hypothesis of its introduction accompanying its trade routes, later consolidated by the stable roman occupation for 400 years.

The mutation IVS1 nt 1, common in other Mediterranean basin countries, reaches the highest reported frequency in the South of Portugal (34\%), decreasing to $17 \%$ both in the Centre and in the North. It is linked to haplotype V ( $\mathrm{Va}$ and $\mathrm{Vb}$ ) as in North African countries. Moreover, we find an atypical association with haplotypes III and IX (Faustino et al., 1992). In Morocco (Lemsaddek et al., 2003) and in Algerian berbers (Bennani et al., 1994) it is associated, respectively, with haplotypes IV and IX, III and IX which have in common the 5' subhaplotype. In the Spanish Alta Extremadura and the Southwest of Spain, it attains a frequency of, respectively 60\% (Ribeiro et al., 1997) and 50\% (Benito et al., 1996). Unfortunately, no haplotypic data exists. This atypical association as well as its predominance in the South of Portugal, suggests that this allele migrated in different genetic backgrounds from Northern Africa to Iberian Peninsula during the long Islamic Berber occupation. The diversity of haplotypes and frameworks argues for an ancient mutational event, probably of Northwest African origin. Data from Y chromosome, date the North African male influence into Iberia as approximately 700 years, up to the conquest of Granada, 1472 (Bosch et al., 2001) but some authors consider that this NW African influence was, at least in part, a consequence of prehistorical links (Arnaiz-Villena et al., 1999; MacaMayer et al., 2003).

Altogether, data on this mutation allows to formulate the following questions: is this mutation in Portugal and Iberia as old as the NW African occupation in Neolithic periods? (haplotype V). Or else, has it been brought later with Islam and haplotypes III and IX? Haplotype data from Andaluzia and Spain would be very useful for a clarification.

The mutation IVS1 nt 6 is the third most frequent mutation with 17\% of relative frequency and reaching a maximum of 30\% in the Centre of Portugal [8]. It is associated with haplotypes VI and VII as in Morocco and different from Algeria, Tunisia and Egypt. As haplotypes VI and VII are dissimilar, except at the 3' region from the hotspot of recombination, we have to postulate a long period of meiotic conversions for the mutation to arise in both haplotypes. This mutation, being common to most of the Mediterranean countries, some authors suggest its origin in the italic peninsula and subsequently spread with the Roman Empire. Its predominance in the Centre of Portugal and in Galicia (50\%, Amselem et al., 1988) does not invalidate this hypothesis. Both regions have in common the same influences of Celts, Romans, Sueves, Visigoths and Arabs. Although the data from Galicia is taken under reserve due to the reduced size of the sample, one should not exclude this possibility.

The mutation Fs cd 6 is interesting as the haplotype data allowed to draw some scenarios of its origin. Described exclusively in the North of Portugal with an abundance of 44\% (Cabeda et al., 1999) is associated with a 
different haplotype from the usual European and North African Fs cd 6 haplotypes. The authors point to an independent origin in Portugal, rest of Europe and Africa or else, a recombination event.

The mutation IVS1 nt 110 is the only one with an even distribution throughout Portugal, associated with haplotype I and a relative frequency of $10 \%$. In Morocco, the frequency is $3.2 \%$. Some authors suggest that it appeared in centuries VIII to VII BC in the Greek population and followed this civilization through the Mediterranean sea (Cao et al., 1989). This hypothesis does not agree with historical data from Portugal. Greeks founded colonies in the east of the IP but there are no archaeological or written records of its presence in Portugal (Fabiao, 1992). Cavalli Sforza argued that the mutation was transported by Phoenicians and Carthaginians in the XII th and XI th centuries BC which sounded more plausible (Sforza et al., 1993). But why, then, is there such a low frequency in Morocco? And why do we observe an exclusive association with haplo-type I? A more extensive study of other Mediterranean populations should be performed in order to answer those questions.

The genetic marker association studies hereby presented are suggestive of movements of genes from Morocco and Northwest Africa to Portugal which is not surprising due to our geographical situation and our history. But questions remain unanswered: do the major $\beta$ thal mutations that we are observing in Portugal represent a genetic image of 500 years of arabo berber occupation or both Portuguese and Moroccan $\beta$ globin mutated genes carry a much older history?

\section{References}

Amselem, S., Nunes, V., Vidaud, M. et al. (1988). Determination of the Spectrum of $\beta$ b Thalassemia Genes in Spain by Dot-Blot Analysis of Amplified $\beta$ Globin DNA. American Journal of Human Genetics, 43, 95-100.

Antonarakis, S., Kazazian Jr., H. H., \& Orkin, S. H. (1985). DNA Polymorphisms and Molecular Pathology of the Human Globin Gene Clusters. Human Genetics, 69, 1-14. http://dx.doi.org/10.1007/BF00295521

Arnaiz-Villena, A. et al. (1999). Iberia: Population Genetics, Anthropology and Linguistics. Human Biology, 71, $725-743$.

Benito, A. (1996). $\beta$ Thalassemia in South-Western Spain: High Frequency of $\beta I V S I-1(G-A)$ Mutation. British Journal of Haematology, 92, 336-338.

Bennani, C., Bouhass, R., Perrin-Percontal, P. et al. (1994). Anthropological Approach to the Heterogeneity of $\beta$ Talassemia Mutations in Northern Africa. Human Biology, 66, 369-382.

Bosch, E. et al. (2001). High Resolution Analysis of Human Y Chromosome Variation Shows a Sharp Discontinuity and Limited Gene Flow between Northwestern Africa and the Iberian Peninsula. American Journal of Human Genetics, 68, 1019-1029. http://dx.doi.org/10.1086/319521

Bruce-Chwatt, L. J., \& Zulueta, J. (1980). Erradicaçao da malária em Portugal. Lisboa: S. E. Saude.

Cabeda, J. M., Correia, C., Estevinho, A. et al. (1999). Unexpected Pattern of $\beta$ Globin Mutations in $\beta$-Thalassaemia Patients from Northern Portugal. British Journal of Haematology, 105, 68-74. http://dx.doi.org/10.1111/j.1365-2141.1999.01295.x

Cao, A., Gossens, M., \& Pirastu, M. (1989). $\beta$ Thalassaemia Mutations in Mediterranean Populations. British Journal of Haematology, 71, 309-312. http://dx.doi.org/10.1111/j.1365-2141.1989.tb04285.x

Chibani, J., Vidaud, M., Duquesnoy, P., Bergé-Lefranc, J. L., Pirastu, M., Ellouze, F. et al. (1988). The Peculiar Spectrum of $\beta$ Thalassemia Genes in Tunisia. Human Genetics, 78, 190-192. http://dx.doi.org/10.1007/BF00278196

Encyclopaedia Britannica (1969). Encyclopaedia Britannica: 200th Anniversary Edition (Vol. 21). Chicago, IL: William Benton Publisher.

Fabião, C. (1992). O passado protohistórico e romano. In J. Matoso (dir.), História de Portugal (Vol. 5, pp. 79-167). Lisboa: Editora Circulo de Leitores.

Faustino, P., Osório-Almeida, L., Barbot, J., Espírito-Santo, D., Gonçalves, J., Romão, L. et al. (1992). Novel Promoter and Splice Junction Defects Add to the Genetic, Clinical or Geographic Heterogeneity of $\beta$ Thalassemia in the Portuguese Population. Human Genetics, 89, 573-576. http://dx.doi.org/10.1007/BF00219188

Faustino, P., Pacheco, P., Loureiro, P., Nogueira, P. J., \& Lavinha, J. (1999). The Geographic Pattern of $\beta$ Thalassaemia Mutations in the Portuguese Population. British Journal of Haematology, 107, 903-904.

http://dx.doi.org/10.1046/j.1365-2141.1999.01821.x

Flint, J., Harding, R., Clegg, J. B., \& Boyce, A. J. (1993). Why Are Some Genetic Diseases Common? Human Genetics, 91, 91-117. http://dx.doi.org/10.1007/BF00222709

Gonçalves, I., Ducrocq, R., Lavinha, J., Nogueira, P. J., Peres, M. J., Picanço, I. et al. (1998). Combined Effect of Two Different Polymorphic Sequences within the Globin Cluster on the Level of HBF. American Journal of Hematology, 57, 269276. http://dx.doi.org/10.1002/(SICI)1096-8652(199804)57:4<269::AID-AJH1>3.0.CO;2-S

Gonçalves, I., Henriques, A., Raimundo, A. et al. (2002). Fetal Hemoglobin Elevation in Hb Lepore Heterozygotes and Its Correlation with $\beta$ Globin Cluster Linked Determinants. American Journal of Hematology, 69, 95-102. 
http://dx.doi.org/10.1002/ajh.10019

Inez, F. et al. (1993). Contribuição do rastreio de portadores para a prevenção da $\beta$ talassémia e da drepanocitose na população portuguesa: Um estudo multicentrico. Arquivos INSA, 19, $27-31$.

Lemsaddek, W. (2005). Analise molecular dos genes de beta e gama globina na populaçao portuguesa e marroquina. Faculdade de Ciências e Tecnologia, Universidade Nova de Lisboa (UNL). Ph.D. Thesis.

Lemsaddek, W., Picanço, I., Seuanes, F. et al. (2003). Spectrum of $\beta$ Thalassemia Mutations and HbF Levels in the Heterozygous Moroccan Population. American Journal of Hematology, 73, 161-168. http://dx.doi.org/10.1002/ajh.10358

Lemsaddek, W., Picanço, I., Seuanes, F. et al. (2004). The $\beta$ Thalassemia Mutation/Haplotype Distribution in the Moroccan Population. Hemoglobin, 28, 25-37. http://dx.doi.org/10.1081/HEM-120028884

Maca-Mayer, N., González, A. M., Pestano, J., Flores, C., Larruga, J. M., \& Cabrera, V. M. (2003). Mitochondrial DNA Transit between West Asia and North Africa Inferred from U6 Phylogeography. BMC Genetics, 4, 15.

Martins, M. C., Olim, G., Melo, J. et al. (1993). Hereditary Anaemias in Portugal: Epidemiology, Public Health Significance and Control. Journal of Medical Genetics, 30, 235-239. http://dx.doi.org/10.1136/jmg.30.3.235

Mata, D. R. (1993). Los fenícios de época arcaica-Siglos VIII/VII a.C. en la Bahia de Cadiz. Estado de la cuestion. In E. Orientais (Ed.), Os Fenícios no território Português (Vol. 4, pp. 23-72). Lisboa: UNL, Instituto Oriental.

Pirastu, M. et al. (1988). Delineation of Specific $\beta$ Thalassemia Mutations in High Risk Areas of Italy: A Prerequisite for Prenatal Diagnosis. Blood, 71, 983-988.

Ribeiro, M. L. et al. (1997). Genetic Heterogeneity of $\beta$ Thalassemia in Populations of the Iberian Peninsula. Hemoglobin, 21, 261-269. http://dx.doi.org/10.3109/03630269708997387

Rosatelli, M. C., Tuveri, T., Scalas, M. T., Leoni, G. B., Sardu, R., Faà, V. et al. (1992). Molecular Screening and Fetal Diagnosis of $\beta$ Thalassemia in the Italian Population. Human Genetics, 89, 585-589.

Rouabhi, F., Amselem, S., Krishnamoorthy, R., Adjrad, L., Girot, R., Chardin, P. et al. (1988). DNA Haplotype Distribution in Algerian $\beta$ Thalassaemia Patients. Human Genetics, 79, 373-376. http://dx.doi.org/10.1007/BF00282180

Schiliro, G., di Gregorio, F., Samperi, P., Mirabile, E., Liang, R., Cürük, M. A. et al. (1995). Genetic Heterogeneity of $\beta$ Thalassemia in Southeast Sicily. American Journal of Hematology, 48, 5-11. http://dx.doi.org/10.1002/ajh.2830480103

Sforza, C. et al. (1993). Demic Expansions and Human Evolution. Science, 259, 639-646. http://dx.doi.org/10.1126/science.8430313

Tavares, A. A. (1993). Fenícios e Massienos na Península Ibérica. In E. Orientais (Ed.), Os Fenícios no território Português (Vol. 4). Lisboa: Instituto Oriental, UNL.

Torres, C. (1992). O Gharb Al Andaluz. In J. Matoso (dir.), História de Portugal (Vol. 5, pp. 363-441). Lisboa: Circulo de Leitores.

Varela Gomes, M. (1993). O estabelecimento fenício-púnico do Cerro da Rocha Branca (Silves). In E. Orientais (Ed.), Os Fenícios no território (Vol. 4, pp. 73-107). Lisboa: Instituto Oriental, UNL.

Waye, J. S., Borys, S., Eng, B., Patterson, M., Chui, D. H. K., Badr El-Din, O. M. K. et al. (1999). Spectrum of $\beta$ Thalassemia Mutations in Egypt. Hemoglobin, 23, 225-261. http://dx.doi.org/10.3109/03630269909005706 